\title{
Order and conflict
}

Anthony Ascham and

English political thought, ${ }_{1648-50}$ 


\section{Order and conflict}

\section{MANCHESTER \\ 1824}

Manchester University Press 
Politics, culture and society in early modern Britain

General editors

DR ALEXANDRA GAJDA

PROFESSOR ANTHONY MILTON

PROFESSOR PETER LAKE

DR JASON PEACEY

This important series publishes monographs that take a fresh and challenging look at the interactions between politics, culture and society in Britain between I500 and the mid-eighteenth century. It counteracts the fragmentation of current historiography through encouraging a variety of approaches which attempt to redefine the political, social and cultural worlds, and to explore their interconnection in a flexible and creative fashion. All the volumes in the series question and transcend traditional interdisciplinary boundaries, such as those between political history and literary studies, social history and divinity, urban history and anthropology. They thus contribute to a broader understanding of crucial developments in early modern Britain.

Recently published in the series

Chaplains in early modern England: Patronage, literature and religion HUGH ADLINGTON, TOM LOCKWOOD AND GILLIAN WRIGHT (eds)

The Cooke sisters: Education, piety and patronage in early modern England GEMMA ALLEN

Black Bartholomew's Day DAVID J. APPLEBY

Insular Christianity ROBERT ARMSTRONG AND TADHG Ó HANNRACHAIN (eds)

Reading and politics in early modern England GEOFF BAKER

'No historie so meete' JAN BROADWAY

Republican learning JUSTIN CHAMPION

News and rumour in Jacobean England: Information, court politics and diplomacy, 1618-25 DAVID COAST

This England PATRICK COLLINSON

Sir Robert Filmer (1588-1653) and the patriotic monarch CESARE CUTTICA

Brave community JOHN GURNEY

'Black Tom' ANDREW HOPPER

Impostures in early modern England: Representations and perceptions of

fraudulent identities TOBIAS B. HUG

The politics of the public sphere in early modern England

PETER LAKE AND STEVEN PINCUS (eds)

Henry Neville and English republican culture GABY MAHLBERG

Royalists and Royalism during the Interregnum JASON MCELLIGOTT AND DAVID L. SMITH

Laudian and Royalist polemic in Stuart England ANTHONY MILTON

Full details of the series are available at www.manchesteruniversitypress.com. 


\title{
Order and conflict
}

\section{Anthony Ascham and English political thought, 1648-50}

\author{
MARCO BARDUCCI
}

Manchester University Press 


\section{Copyright (C) Marco Barducci 20I5}

The right of Marco Barducci to be identified as the author of this work has been asserted by him in accordance with the Copyright, Designs and Patents Act I988.

Published by Manchester University Press

Altrincham Street, Manchester Mi 7JA

www.manchesteruniversitypress.co.uk

British Library Cataloguing-in-Publication Data

A catalogue record for this book is available from the British Library

Library of Congress Cataloging-in-Publication Data applied for

ISBN 978 ○ 7190 9680 8 hardback

First published 2015

The publisher has no responsibility for the persistence or accuracy of URLs for any external or third-party internet websites referred to in this book, and does not guarantee that any content on such websites is, or will remain, accurate or appropriate.

Edited and typeset

by Frances Hackeson Freelance Publishing Services, Brinscall, Lancs 